\title{
From Gada Merin to Jesse James: A Comparative Study on the Image of Heroes in Mongolian Horqin Folk Songs and American Western Cowboy Songs
}

\author{
Shuanglian Chen $^{1}$ \\ ${ }^{1}$ School of Foreign Languages, Inner Mongolia University for the Nationalities, China \\ Correspondence: Shuanglian Chen, Tongliao, School of Foreign Languages, Inner Mongolia University for the \\ Nationalities, Tongliao City, Inner Mongolia, China. Tel: 86-139-4758-2115. E-mail: chenshuanglian@163.com
}

Received: September 11, 2014 Accepted: November 2, 2014 Online Published: November 25, 2014

doi:10.5539/ells.v4n4p86 URL: http://dx.doi.org/10.5539/ells.v4n4p86

\begin{abstract}
Every country has a folk culture unique to that country, every ethnic group has a folk culture unique to that ethnic group. Folk songs are the core of a folk culture. The original life styles, thoughts, values of a people all find their expressions in folk songs. Hero songs make up a premier category of Horqin folk songs. The American cowboy songs present a perfect image of a hero which accords with the expectation of American myth. This paper tries to build a bridge between the two seemingly distant cultures by taking Gada Merin and Jesse James as examples to compare the image of heroes in Mongolian Horqin folk songs with that in American western cowboy songs. Both folk songs are trying to present the real stories of authentic people. The characters in both songs are courageous, bold and wise; but they both seem to come to bad ends in the similar ways. The tragic fate of Gada Merin and the bad reputation of Jesse James do not interfere with their popularity among people. But the dissimilarities are more obvious. The different historical and cultural backgrounds create different kinds of heroes. Horqin heroes, with particular political goals, are better organized and better educated. Horqin heroes more cherish collective honor while American cowboy heroes more indulge in individualism and heroism.
\end{abstract}

Keywords: Horqin folk songs, American cowboy songs, hero, image, comparative study

\section{Introduction}

Culture is the cohesion of some common characteristics of human society such as history, religions, faith, traditions, customs and other social consciousness of a nation. It also finds its expression in the literature, movies, architecture and costumes. Folk songs, as a branch of literature and art, reflect the original life styles, mode of thinking, values of a nation. At the same time, culture also witnesses history. So people can bring back the authentic historic truth and life of an ethnic group by conducting a close research on folk songs.

"Every race has a folk culture peculiar to that race; every country has a folk culture peculiar to that country; every section has a folk culture peculiar to that section; every occupation has a folk culture peculiar to that occupation. Basically, folk culture is a universal quality to be found to the same degree in all races, countries, sections and occupations... The cowboy is no exception to this universal rule. He too sings songs and tells tales of work, death, heroes, love, amusement, humor, and religion (Cadlo, 1947, p. 335)." Horqin folk songs are an important cultural heritage of eastern Mongolians. They tell people the changes of life and thinking of Horqin Mongolians from the thirteenth century. And the American western cowboy songs mark the poignant history of people in the American westward movement. Culture is the essence of a nation and it never exists in isolation. Many similarities can be found between the two distinct cultures. Because people are hoping to express their own feelings whether they are singing or dancing, playing a musical instrument or composing a prose. The feelings people hope to express are similar. Culture is based on shared values. So why do these two cultures create such heroic images? What are the similarities and dissimilarities of them? This article will be the answer to these questions.

\subsection{Horqin Folk Songs}

Horqin Mongols is an ethnic group that settles in the eastern area of Inner Mongolia, a far northern province of China. They are believed to be the direct descendents of Kasar, a sibling of Genghis Khan. Horqin culture is an important component of Mongolian culture. And folk songs, as an important cultural heritage, are the core of this 
culture and they always reflect the wisdom of their people. Horqin folk songs have the features of wide varieties, rich contents, considerable quantity, elaborate language and beautiful melody. Many kinds of local-born characters are vividly shown in front of the audience in those Horqin hero songs, love songs, homesick songs and humor songs. Horqin folk songs also include hunting songs, herding songs, legend songs, tales songs etc. There are also many other kinds according to different classifications.

Horqin folk songs are a representative of the eastern Mongolian songs and they have their obvious literary features. The heroes in Horqin folk songs can be divided into two kinds. The first kind is those heroes in manges uligers (heroic epics). The heroes like Geser Bogd in those songs are usually fictitious and they are given a magic power. There is another kind of hero songs which describe some outstanding people who did some heroic deeds for his people. The typical hero songs of this kind include Gada Merin, Danabala, Balji Nima, Zhana and Togteg. They mainly sing the rebellious spirit, accuse the oppression and military service and praise the heroic figures. These long narrative folk songs are very popular because of their beautiful melody, intricate themes, touching plots and vivid language. These songs, by employing a lot of rhetorical devices such as comparison, repetition, hyperbole, parallelism and personification, tend to present complete plots and clear themes. They also have the features of having numerous characters and reflecting some major social issues. They are spread and handed down with the help of many folk singers.

\subsection{American Western Cowboy Songs}

What the American western folk song tells audiences is a historic period in the development of American civilization. The cowboy songs mainly tell the hardships and sorrow of people when they explore the Wild West. A cowboy, an animal herder who tends cattle on ranches in North America, traditionally on horseback, often performs a multitude of other ranch-related tasks. The cowboy has deep historic roots tracing back to Spain and the earliest European settlers of the Americans (Western music, 2014). They are also called cow-ranchers, wranglers, vaqueros and cow-punchers. In order to spend the boring days on the boundless disserted prairie, they coined a large number of cowboy songs during their tedious herding work. These cowboy songs are famous for their vast varieties, simple language, fewer characters and highlighted themes. This rich folk culture adds flavor to American culture. The cowboys, a generation on the horseback, create a lot of generous and heroic images. There are two kinds of heroes in cowboy songs. The first kind emphasizes heroic deeds of some unknown heroes such as the characters in Utah Carroll, The Stampede, Panhandle Cob and The Texas Rangers. "In these songs, the feats of heroism are not performed by an individual but by a whole unit or group (Cadlo, 1947, p. 337)." However, the second kind of hero songs highlights the individualism and freedom. These songs include Jesse James, Sam Bass, Billy the Kid, Wild Bill, I've Got No Use for the Women.

Cowboy music is typical among American western music, and it has some distinct characteristics. "Western music celebrates the life of the cowboy on the open ranges and prairies of Western North America (Western music, 2014)." With the spread of American culture, the images of western cowboys are so deeply rooted in the hearts of people. The unique costumes, language, melody and forms of entertainment of cowboys are shown through the performances and interpretation of world people. And these gradually consist of the cowboy culture. If the western spirit reflected on the western cowboys forms the original element of American spirit, the image of cowboys in western literature shapes the American myth which becomes the symbol of America. The cowboy songs in the western literature publicize the pioneering spirit of cowboys by describing their struggle for the survival against the hard life in the Wild West. The national spirit which tempered in that special environment is the core of the American spirit.

The characters molded in both Mongolian Horqin folk songs and the American western cowboy songs become their national pride and a symbol of an era. In the process of connecting the culture of American Wild West with that of Horqin Mongols, the author finds that there are a lot of similarities between the two. This article tries to build a bridge of communication between the far two seemingly different cultures by digging into the similarities and dissimilarities between the two heroes, Gada Merin and Jesse James. And the comparison of the images is made 1) through the analysis of the phrases and sentences form both songs, 2) through the tone of the both songs, 3) through the evaluation on the images from other publications.

\section{Similarities of Both Heroes}

As representative hero songs of their people, Gada Merin and Jesse James have many things in common. They are both based on the real stories of authentic people. Their tragic fate is so similar. They are skillful at shooting and horse riding. Perhaps, Gada is not a herdsman himself and Jesse maybe a cowboy for only a short time. These brave and bold men, having a strong sense of justice and being ready to revolt against the power and to help the weak, have become legendary heroes. They might not have done very extraordinary things but they have 
been deeply rooted in the hearts of people.

\subsection{Real Stories of Authentic People}

The stories of Gada Merin and Jesse James are based on facts. They are not supermen, they are just ordinary people in our neighborhood. The Horqin folk song, Gada Merin is a household song in the eastern Inner Mongolia. The protagonist Gada Merin was born in 1892 in the Darhan Banner of Jirim League, which is the present day Horqin Zuoyi Zhongqi of Tongliao City in Inner Mongolia. In order to protect the grasslands and oppose the agricultural reclamation, he, together with his followers, revolted against the local authority and the aggressors in 1929 after his petition had been turned down. But he and his army met with the brutal repression of the warlord Zhang Zuolin and the local authority Namjile. Gada and his army were besieged by the Wulji Muren River and he lost his young life there. It was the year of 1931.

The story of Jesse James is very popular in America. As a legendary figure, there are several versions of his story. "He is an iconic figure in the western culture of North America after the Civil War (Christopher, 1986, p. 43)." Jesse was born in Clay County of Missouri on September 5, 1847. Jesse and his brother Frank, together with his followers stopped the trains and stagecoaches, robbed the banks. On April $3^{\text {rd }}, 1882$, Jesse was murdered in his own house and his assassin was Robert Ford who had joined Jesse's group short time before with the deliberate intent of killing him and claiming the $\$ 10,000$ reward offered for the deed (Silber, 1967, p. 257).

The tragic fate of Horqin heroes is so similar to that of cowboy heroes. They fought against the warlord or the local authority. Some of them were killed on the battle fields while others were betrayed by some evil men. Gada Merin and his army were besieged and killed in Wulji Muren River and Jesse James was betrayed by Robert Ford, his one-time friend, who gave him a fatal bullet on the back of his head.

The more people love the hero, the more they hate the man who frames the hero. Gada Merin is compared to a swan goose who likes to fall on the beautiful grasslands. They call the enemy who killed Gada as "a bastard". In the hearts of many Americans, Jesse is not a real hero. Many call him an outlaw. But people harbor a tolerant attitude towards this hero who "stole from the rich and gave to the poor" and some even express their genuine love towards this outlaw. People could not help feeling sad when the news of his death arrived. National Police Gazette called the hideous assassination of him as "the deed of a dastard". The Kansas City Daily Journal published an article under the name of "Goodbye Jesse!" to report his death. And "to the Southerners in the Missouri legislature, Jesse and his boys could do no wrong (Horan, 1959, p. 226)." He became a national hero.

\subsection{The Same Quality of Heroes}

The talents of Horqin heroes and cowboy heroes are heightened by their courage, decisiveness and chivalry. They are brave and skillful in battles, horse-riding and shooting. Horqin heroes as Gada Merin, Zhana, Balji Nima did not shrink form danger, hardships and they fought bravely against the invaders and the local authority for the sake of their own people. As Ma Zhuangzhi puts it, "Gada Merin sacrificed his life in order to fight against the feudalism and warlords and for the sake of the lands of his people. He is the earliest hero both in China and in the world who lost his life for the sake of environmental protection. He belongs not only to Mongols, but also to China or even to the world. He is the son of the earth and a patron saint of the grassland (Ma, 2004, p. 321)." Western cowboys such as Jesse James and Sam Bass are also bold and brave. They are usually strongly built. They wrestle with the local sheriffs and governments boldly and tactfully. They are a combination of an unyielding heroic spirit and a brave pioneering spirit. They are hard working and tolerant. They are not scared by Indians, rattlesnakes, stampedes, coyotes and all other hardships in the Wild West. They were galloping across the unpopulated North American land by their sheer diligence, courage, adventurousness and also with their positive attitudes towards life.

The folk heroes are the outcome of the local culture. Folk songs usually give supernatural power to their heroes in order to highlight the image of heroes. These legendary figures usually met with bad ends because of various reasons. The songs are full of tragic tone. Some lines of the songs sound mild and pleasant, but others seem full of indignation. The audiences are unconsciously brought into the life of the characters. Then the audiences begin to worry about the fate of them. In the song Gada Merin, the following lines are full of tragic tone:

We, my Mongolians, could no longer afford the sheepskin jackets,

We have lost the pastures,

The pastures had been sold out by our Darhan Wang,

To the bastard Zhang Zuolin as farm land.

However the following lines are filled with the indignation of people towards the murderer: 
Well it was Robert Ford, that dirty little coward,

I wonder how he does feel,

For he ate of Jesse's bread and he slept in Jesse's bed,

Then he laid poor Jesse in his grave.

\subsection{The Similar Geographical Environment}

The traditional Mongolians have herded livestock for a living for generations. They used to choose a nomadic life so they always moved about in search of fine grass and clean water. So losing a pasture means losing the herds to live on. And with their exquisite skills of horse-riding, the western cowboys conquered the cattle all over the mountains and prairies, defeated the Indians who attacked them during the night, beat back the marshals who came to capture them for fear of the growth of their team. The cowboys lived on the sparsely-populated North American prairies where they also settled down for the grass and water.

Both songs form in a similar way. Herdsmen, either by singing or by shouting, like to express their special affections towards the grasslands and relieve themselves of the loneliness caused because of inability to reach anybody and anything on such an unpopulated land. Both heroes enjoy the feelings of being the conquerors on the horseback and killing the enemies. They like to expose themselves to the wild nature. They usually stay outside overnight by the campfire with their saddles as pillows and with their horses as their companions. This seemingly primitive life is the way of their perceiving life and rejecting the main stream. What their life deduces is a harmonious integration of man and nature. So the both Horqin heroes and cowboy heroes are the products of prairies.

\section{Dissimilarities of Both Heroes}

The folk culture witnesses the ups and downs of a people. By carrying out a study on folk culture, men can unearth the true history and original life of that people. Because different races experience different histories in their development, there definitely exist some differences in their cultures. And these significant differences are also shown in their folk songs.

\subsection{Different Historical Backgrounds}

The historical backgrounds of Horqin folk hero songs and western cowboy hero songs are significantly different. The differences are especially distinct when it comes to the backgrounds of Gada Merin and Jesse James.

The revolt of Mongolian Horqin folk heroes as Gada Merin took place on the Mongolian grassland under the rule of Qing Dynasty at the end of $19^{\text {th }}$ century. At that time the grassland was full of internal and external conflicts. In order to relieve the political and economic contradictions at home and to boost the government revenue, the Qing government decided to carry out the policy of "Cultivate the land of Mongolian and strengthen the border area by migration". This policy intended to strengthen the border and to alleviate the contradictions between Mongols and Han Chinese. At that time, many Mongolian Wangs sold the grassland for power and money. As a result, most herdsmen lost their grasslands where they lived for generations. But they were confronted with a severe crisis for survival. Gada was worried at the daily decrease of their land and hard life of his people. Merin is his official. As an official, he petitioned to return the land to the herdsmen but was refused. So Gada Merin, together with his own army, was forced to rebel against the authority in 1929. The reason of his revolt is also written in the song:

The swan goose who flies from the south,

Will definitely rest on the Xira Muren River.

The reason of Gada Merin's revolt is to,

Win back the land of Mongolian people.

The time of Jesse was a little earlier than that of Gada. At 1860s, right after the Civil War, the booming of American cattle industry and the invention of refrigerated train make it possible to transport the fresh beef to far-away areas. The long cattle drive and the big corral all need more hands to lead and look after the cattle, which tempted a large number of young men to flock to the western towns and villages. There are also many other reasons for them to go west. "the postwar influx of ex-soldiers and restless young men inured to killing and violence, the peculiar nature of the mining towns, the peculiar nature of cattle business, the romantic accounts in popular periodicals of the glamorized Robin-Hoodized bandits and their counterparts, the sheriffs and marshals... Civil War many ex-soldiers, Union and Confederate, bored or dissatisfied with the dull life back home, made their way West (Horan, 1959, p. 226)." All these reasons seem not enough. The adventurousness of 
Americans also adds their own little matchsticks to that craziness. The ex-slaves, some Indians and Mexicans from the border, together with those young men who seek the freedom and opportunity in the west, joined the group. Later these people are called "the generation on the horseback". Most of the western cowboy heroes hope to find their freedom and realize their dream in the Wild West. But Jesse James and his brother Frank James seemed to have more reasons for their revolt. The following lines tell the reasons of their revolt:

They was living on a farm in the old Missouri hills,

With a silver-haired mother and a home;

Now the railroad bullies come to chase them off their land,

But they found that Frank and Jesse wouldn't run.

Then a railroad scab, he went and got a bomb,

And he throwed it at the door-

And it killed Mrs. James a-sleeping in her bed,

So Jesse grabbed a big forty-four.

The railways occupied their land and the railroad scab killed their mother. So the both brothers determined to fight against the oppressors with their guns. The saying that "Heroes emerge in troubled times" seems verified.

\subsection{Different Forms of Fighting}

The forms of fighting of Horqin heroes and cowboy heroes are different. The Horqin heroes as Gada, Balji and Togteg are not lonely. They have brothers and sisters who fight with them. They also have hundreds of supporters behind them. What is usually emphasized in Horqin hero songs is the class struggle. They are fighting for the collective interest or the benefit of the whole. These Mongolian heroes are well organized and have a strong sense of collective honor. Their armies are principled. The soldiers who broke the rules would be punished severely.

This becomes a striking contrast against the western cowboy heroes. The western cowboy heroes fight with not too much help around. Compared with Horqin heroes, they fight in a small group or even on their own. They are much more like Robin Hood who is "stealing from the rich, generous with the poor (Silber, 1967, p. 257)." These wandering heroes are "independent and perhaps irresponsible. With no domestic worries and no worthwhile possessions outside a gun and a horse... (Monaghan, 1963, p. 330)" Even when some brothers, cousins and friends joined the group, the cowboy group was still so small. They are bold and courageous but what they are lack is some political purposes and proper means of fighting.

\subsection{Different Themes and Focus}

Because of different cultural practice, the themes of the folk songs and expectation of the audience are quite different. The collectivism is so strongly emphasized in Horqin folk songs, while individualism is heightened in western cowboy songs. In Horqin hero songs, the national affections are stressed and different kinds of words are employed to praise or criticize the characters in the songs. Some derogatory words such as "bastard, sly fox, thief lord" are used to describe the warlord Zhang Zuolin and "wily, scorpions-hearted" for his wife. And many commendatory words are used to describe the heroes. However when it comes to the description of outward appearance of a hero, very few words and phrases are found. What the Horqin heroes as Gada Merin seek is the justice.

The personality of cowboy heroes is especially emphasized in the western cowboy songs. Individualism and heroism are highlighted. The writers of fictions and the directors of movies never grudge their words when molding an image of a cowboy. Cowboys were galloping on the horses with broad rimmed hats, leather coats, jeans and high heels with scarves around their necks and with pistols and rifles on their shoulders. What they represent is the typical individualism and freedom. These handsome cowboys, somewhat encouraged by American adventurousness and their passion for the American dream, departed from the eastern civilized world alone. Most of them are calm, wise, and of dauntless persistence. "hardship, isolation and danger were the substance of the cowboy's life and they developed his sterner qualities to a high degree.... It is interesting to review the characteristics of the typical cowboy. No one was more generous, with time and money. He would share anything with a fellow rider. Loyalty to the "iron," or brand, was universal. Concern for the cattle, the property of his outfit, came first and he shrugged off any consideration of risk to his own life or limb.... His word is his bond. In early Texas days, deals were made, cattle bought and sold, herds changed hands, on a mere say-so. 
A man's word was enough (Monaghan, 1963, p. 331).” These qualities accord with the perfect image of a hero in the hearts of Americans.

Some cowboy heroes are controversial figures. Many people only approve the unknown heroes in the stampede or cattle drive. Some even call the heroes such as Jesse James and Sam Bass as the "outlaw", "daring desperado", "gang", "bandit", "lawless" or "badlands". Maybe the cowboys earned some bad reputation because of their personality of seeking short time pleasure and temporary novelties. As Bakken puts it, "To many people, settling on a single interpretation of these late nineteen century characters is almost impossible. The cowboy easily and equally calls to mind campfires and harmonica tunes, stampedes and whirling lassos, heroic deeds and mysterious identities, and fast-drawing gun-slinging justice.... Clearly, these multiple images are conflations of history and story (Bakken, 2008, p. 66)"

\section{Conclusion}

Folk songs can help to inherit and develop the culture. They can also strengthen the national sense of cohesion and pride. Therefore they help to promote national quality and national vision. Folk songs not only contain the values, thinking modes and other cultural consciousness of a nation, but also embody the vitality and creativity of a nation or an ethnic group.

Of the two heroes, it is hard to say one is better than the other. The both songs are produced in the similar way. People sing these songs to get rid of loneliness and fatigue because of longtime herding on the vast land with nobody beside and no family members helping and talking to them. These two narrative songs both promote the same theme of harmony between the human and nature. The characters and stories in both hero songs are based on the real people in life. Horqin hero folk songs usually cover bigger and serious topics and they emphasize the conflict between different races. Different from cowboy hero songs with simple plots and less characters, Horqin folk hero songs tend to present the audience some stories with complicated plots and multiple characters. The story of Gada Merin is talked again today for it is supposed to cover the topic of environmental protection for its theme of fighting against the agricultural reclamation and protecting the grasslands. All these consist of the core of Horqin folk culture, which becomes the indispensable part of the Mongolian culture.

The image of the American Western cowboys is much more complicated than that of Mongolian Horqin hero. The lonely western cowboy heroes differ from the tragic national heroes on the Mongolian Horqin grasslands. The characters created by the Americans in order to satisfy their own needs for perfect image of themselves are unique. The herding skills of cowboys are usually exaggerated and sometimes the behaviors of those outlaws are given the color of romanticism. The song Jesse James does not cover big issues. The western cowboys in real life are mostly ordinary herdsmen compared with the outstanding Horqin heroes. The heroes such as Jesse James are outlaws. But what is strange about them is that these outlaws are as popular as the Horqin heroes among his people. This is the biggest dissimilarity between Horqin folk heroes and American western cowboy heroes. And the distinct family background is another difference. Horqin heroes usually grow up in wealthier families and Gada Merin is even a junior official when he revolts against the local authority. Most cowboy heroes are from the working class in that particular historical period in America. They are the exploited. However the wealthy background of Horqin heroes on the other side highlights their greatness. They revolt against the existing society not for their own personal gains but for the right cause. The main task of western cowboys is to herd which is a boring and difficult job. But what is interesting is that these cowboys are described as being manly and brave, humble and chivalrous in the movies and fictions. Although the great prosperity period of cowboys fades away very soon, the progressive and pioneering spirit of cowboys encourage the generations of Americans. And this spirit becomes the symbol of American spirit. Cowboy culture becomes not only a component part of the American culture but also becomes a typical culture in the world culture.

\section{Acknowledgements}

Here I express my gratitude to Inner Mongolia University for the Nationalities who has offered me a chance to conduct a research program named A Comparative Study on Images in Mongolian Horqin Folk Songs and American Western Folk Songs (NMD1361). This is one of the articles designed for this program. My thanks will especially go to Dr. Jack R. Rollwagen, a knowledgeable anthropologist and professor at the College at Brockport, State University of New York who has given me a generous help during my research in America. Besides I also feel grateful to those people who have been trying to pass on such beautiful folk songs to the next generation.

\section{References}

Bakken, G. M. (2008). Icons of the American West: from cowgirls to Silicon Valley (Vol. 1, p. 66). Westport, 
Conn.: Greenwood Press.

Bao, S. (2009). A Study of Horqin Folk Songs. Tongliao: Inner Mongolia Children's Publishing House.

Botkin, B. A. (Ed.). (1994). A Treasury of American Folklore, stories, ballads, and traditions of the people. New York: Crown Publishers.

Cadlo, J. J. (1947). Cowboy Life as Reflected in Cowboy Songs, Western Folklore (pp. 335-337). Long Beach: Western States Folklore Society.

Christopher, A. (1986). Jesse James, the Bourgeois Bandit: The Transformation of a Popular Hero, Cinema Journal (p. 43). Austin: University of Texas Press.

Erdumtu \& Menghe. (2002). Cutural History of Horqin. Huhhot: Inner Mongol People Publishing House.

Horan, J. D. (1959). The Great American West: A pictorial History from Coronado to the Last Frontier (p. 226). New York: Crown Publishers, Inc.

Lingenfelter, R. E., Dwyer, R. A., \& Cohen, D. (1968). Songs of the American West. Berkeley: University of California Press.

Lomax, J. A., Lomax, A., \& Waters, E. N. (1938). Cowboy Songs and Other Frontier Ballads. New York: The Macmillan company. Retrieved from http://en.wikipedia.org/wiki/Western_music_(North_America)

Ma, Z. Z. (2004). Horqin Historical Figures (p. 321). Huhhot: Inner Mongol People Publishing House.

Monaghan, J. (Ed.). (1963). The Book of the American West (pp. 330-331). New York: Julian Messner Inc.

Silber, I. (Ed. \& Comp.). (1967). Songs of the Great American West (p. 257). New York: The Macmillan Company.

Tichi, C. (1994). High Lonesome: The American Culture of Country Music. Chapel Hill: The University of North Carolina Press.

Tinsley, J. B. (1981). He Was Singing This Song: a collection of 48 traditional songs of the American cowboys with words, music pictures and songs. Orlando: University Press of Florida.

Western Music (North America). In Wikipedia, the free encyclopedia. Retrieved from http://en.wikipedia.org/wiki/Western_music_(North_America)

Zhu, S. J. (2011). Gada Merin. Beijing: People’s Literature Publishing House.

\section{Copyrights}

Copyright for this article is retained by the author(s), with first publication rights granted to the journal.

This is an open-access article distributed under the terms and conditions of the Creative Commons Attribution license (http://creativecommons.org/licenses/by/3.0/). 